\title{
Porter's Diamond Factor Conditions Determinant: Effect on Automotive Industry of Pakistan
}

\author{
Muhammad Ahmed Butt, Paul Katuse, and Juliana M. Namada
}

\begin{abstract}
The purpose of the study was to investigate Porter's diamond attribute factor conditions influence on the performance of firms in the automotive industry of Pakistan. Research methodology used positivism philosophy, data collection instrument used was the structured questionnaire after conducting the pilot study; cross-sectional design was constructed, probability method constituted the data collection approach, parametric and nonparametric statistics used to analyze the data, and hypothesis tested using regression model. The sample size was 194 respondents. The research study found out that there is non-availability of empirical studies on Porter's diamond in Pakistan. Porter's diamond factor conditions determinant conceptual and theoretical theme has the potential to provide $C A$ to the industry. Conclusively the study pointed out the underlying force of factor conditions being one of the attributes of Porter's diamond having significant influence on the performance of the automotive industry of Pakistan. The study examined the automotive industry exclusively from the perspective of private, multinational corporations (MNCs) and joint ventures. There are strategic practical implications of the study findings for academia, practitioners, and government constituencies. The significance of the study lies in the pragmatic perspective provided to the automotives industry players and the government policy makers in realizing the national competitive advantage (NCA) by internalizing the factor conditions as an attribute of Porter's diamond.
\end{abstract}

Index Terms-Automotive Industry; Competitive Advantage; Factor Conditions; National Competitive Advantage

\section{INTRODUCTION}

Competitiveness of firms, industries and nations is an intriguing subject and a very compelling area of study for researchers. Scholar [1] of Harvard University undertook a profound study capturing 100 industries representing various sectors in 10 different States of the world to address a critical question, how the United States (US) achieved and maintained competitive advantage (CA) internationally? After extensive investigation and analysis Porter inferred conclusively that success of States while competing globally is dependent on four key determinants presented in diamond framework, namely, factor conditions component, demand conditions component, related \& supporting industries, and firm strategy,

\footnotetext{
Muhammad Ahmed Butt, Doctoral Candidate, United States Internationa University-Africa. Doctoral Program, Nairobi, Kenya. (e-mail: mabparadigms@yahoo.com)

Prof. Paul Katuse PhD. United States International University-Africa. (email: info@usiu.ac.ke)

Prof. Juliana M. Namada PhD. United States International UniversityAfrica. (e-mail: info@usiu.ac.ke)
}

structure and rivalry [2]. A number of studies have focused on the four key attributes of Porter's diamond framework, including the theoretical aspect, practical managerial implications as well as the relevance of Porter's diamond model for policy making institutions.

The four diamond attributes linked with national competitive advantage (NCA) shape the competitive environment for industries. Porter's diamond model presents a framework to carry out industry specific analysis to determine its performance and competitiveness while operating in the country [3]. The author [4] observed that the linkage and interaction of these determinants with each other constitute the country's diamond, and determine the national competitiveness. Factor conditions include workforce which is industry-specific and possesses high degree of skills, availability of adequate investment and funds so that firm may endeavor to acquire knowledge and information being specialized inputs Porter, 1990.

The researcher attempted through empirical research to investigate the problem in the context of Pakistan anchoring the diamond framework theory in the key automotive industry. The results from developed countries like USA, UK, Germany and Japan affirm the applicability of diamond model in driving the state to NCA and creating CA in given industries. In contrast, in developing economies like South Korea, China, Portugal, and India, the findings of Porter's diamond framework revealed mixed results; from among the four broad based major determinants of the model individual components, factor conditions and clusters of related and supporting industry helped the firms to have CA, increasing the competitiveness of the industry leading to NCA. Disregarding the degree of economic development of the countries and industry complexity one common factor of these studies remained the underlying theme to understand the reliability of diamond model, its benefits to industry and to nations at large in terms of realizing the NCA and CA.

This made the researcher investigate whether in Pakistan Porter's diamond model can resolve the dilemma confronted by key automotive sector in realizing the CA and investigate the effect of Porter's diamond factor conditions on firm's performance. The automotive industry in Pakistan has fairly long history of manufacturing diverse vehicles vis-à-vis other Asian countries. Performance and competitiveness of the automotive industry in Pakistan remained a consistent concern to policy makers and corporate practitioners alike. The reference [5] study noted underperformance of auto industry in Pakistan. In Pakistan, automotive sector makes a sizeable contribution to the economy in terms of investment, value added, employment and revenues. Pakistan's automotive sector 
registered growth in 2015,documenting 23.5 percent cumulative [6] reflecting critical importance of this industry.

Government of Pakistan did make several interventions including the introduction of pragmatic policy [7] which also highlighted that past government policies related to automotive industry sector performed below expectations inclusive of policy objectives, and achieving sustainable development in the sector, yet the government of Pakistan depends on the performance and international competitiveness of this large scale manufacturing sector of the economy. Therefore, the question essentially required to be answered was whether Porter's diamond model factor conditions determinant influences the performance of firms constituting the automotive sector of Pakistan.

\section{A. Hypothesis}

The specific objective which guided the research carried out in Pakistan's auto industry was to assess the effect of factor conditions as a determinant of firm's performance. The null hypothesis for the survey was guided by the specific objective of the study; H01: Porter's diamond factor conditions determinant does not affect firm's performance.

\section{LITERATURE REVIEW}

\section{A. Theoretical perspective}

The researcher [8] explains theoretical framework as applying the theory, or drawing a group of concepts of the same theory to present and shed light on the specific phenomena, research agenda or elaboration of event. This study was guided by Porter's diamond theory determinants. The nation's situation in skilled workforce or infrastructure is termed as factors of production. Porter explained that by and large national factors of production encompass things and resources accessible to economic entities, such as physical, financial, and human resources. It goes beyond saying that resources include quality of infrastructure in a country's health care and education systems, transportation and communication networks. These resources provide impetus in creating value with productivity. Porter, however, argued aptly that human capital, and knowledge, considered as advanced factors are having greater importance vis-à-vis basic factors; incidentally this theme is true especially in current global information-oriented economies. Needless to reiterate that for firms competing in the fiercely competitive market, factor conditions are essential inputs and may cluster into five key resources, namely, physical, human, knowledge, infrastructure and capital resources. Essentially, competitive strength of group is attributable to factors of productions' availability within the group [9]. The existence of adequate resources does establish stable operation of the group.

\section{B. Empirical literature Review}

In New Zealand at Massey University School of Management,[10] undertook a research to test the hypothesis that increased national competiveness results in better industrial performance, being a strong assumption in formulation of economic policy in Anglo sphere over the last three decades. The research methodology used inductive content analysis. Deregulation has been used massively by the US government and others. This deregulation has its grounds in Porter's framework and Chicago school.

The study inferred that the policy conditions and contributing analysis both failed to focus on the very source of national disadvantage, that is, the Japanese operational practices in 1970s and 1980s which are being implemented even presently and in, by and large, a hidden manner. The study noted critically that Japan's formidable and influencing competitive advantage is fundamentally due to human resource and cited the Japanese phenomenon of managed education in Aichi, the home town of the Toyota firm. In India, the author [11] conducted a research study in Himachal Pradesh, India and investigated competitive positions of various micro, small and medium enterprises (MSMEs) using diamond. The study covered sectors, like, pharmaceuticals, food, automobile, electrical \& electronic goods and textiles. The research design included extensive literature review and exploratory factor analysis. The results drawn from the study revealed that intangible factors influenced the competitiveness of medium and small enterprises, and that these intangible resources are complex to be substituted and imitated by competitors. It was also noted in the study that for various MSMEs diamond axes with regards to diamond determinants are different. Their study and its results have implications for managers and the new entrants in terms of entrepreneurship.

Uganda, the author of [12] Makerere University Business School examined the contribution of intellectual capital at individual's level to gain CA. In his research, he explored intellectual capital's role in microfinance industry of Uganda. In the study, hierarchical regression research design was used; reason being that it indicates results with precision while predictor variables are used in the model. The author affirmed the view that for competitive advantage prediction three intellectual capital elements have 44 percent of variance in CA. The variance in CA according to their order of importance are; structural, human, and relational capital.

In Armenia researchers [13] carried out a study which focused on exploring how to apply the diamond model in economy of the country and in crafting pragmatic development policies. The study in the conclusion made recommendation to place emphasis on encouraging competition and rivalry in the industries and also on appropriate In another study, [14] investigated CA sources focusing on the sports goods cluster in Jalandhar city of India. The study analyzed each determinant of the diamond framework to provide insight and identify the most compelling determinant leading to CA in the cluster. The author divided the study into three parts inclusive of identification of 
theoretical perspective of diamond and cluster related to sports goods. The study concluded and advanced various strategies to improve the structure of cluster on competitive grounds in India and developing countries alike and further drew the conclusion that factor conditions (skilled labor availability and raw material) led to competitiveness in the sports goods cluster of industries.

\section{RESEARCH METHODOLOGY}

The authors [15] aptly explained that research philosophy fundamentally refers to organization of convictions and assumptions regarding knowledge development in a particular field. In the study researcher used the axiology and epistemology for positivism philosophy reason being that positivism serves as deterministic tenet in which rational and logical causes regulate the effects or results. The study included CEOs, senior managers, and functional heads of the automotive firms who were the target population. This study used structured questionnaire to collect the primary data. Developed structured questionnaire's validity and reliability was confirmed in the pilot study.

\section{A. Cronbach's alpha for Factor Conditions}

For reliability coefficient Cronbach alpha was used in pilot study to gauge the degree of internal homogeneity/consistency between variables measuring one concept/construct. According to author [16] coefficient fluctuates from range 0 to 1 , internal homogeneity reliability is unsatisfactory if coefficient value is 0.6 or less than that Acceptable internal consistency reliability measurement spans from .70 to .80 in social sciences field [17]. In this case, $\alpha=$ .73, which shows the factor condition items have internal consistency. Table 1 presents the details

TABLE 1. Cronbach's alpha for Factor Conditions

\begin{tabular}{|c|c|c|}
\hline \multicolumn{3}{|c|}{ Reliability Statistics } \\
\hline $\begin{array}{l}\text { Cronbach's } \\
\text { Alpha }\end{array}$ & $\begin{array}{l}\text { Cronbach's Alpha Based on } \\
\text { Standardized Items }\end{array}$ & $\mathrm{N}$ of Items \\
\hline .733 & .756 & 13 \\
\hline
\end{tabular}

\section{B. Correlation Analysis Model}

According to researchers [18] correlation analysis is termed as using the statistics to determine the strength of linear relationship between two or more variables; systematic changes in a variable results into respective changes in the other. To measure the strength of the linear relationship between two such variables Pearson correlation coefficient is applied. Techniques of correlation coefficient compile the association between two variables into a single digit. Symbol $r$ move from +1 to -1 denote correlation coefficient, however, if correlation coefficient is near to 0 , either positive or negative denotes no relationship. In this study Pearson correction coefficient is used to measure the strength of linear relationship between Porter's diamond factor conditions determinant and firm's performance in the automotive industry of Pakistan.

\section{Chi-Square Test}

According to authors [19] Chi-square is a statistical test used on sets of data being categorical to help determine whether two variables are termed as independent or whether observed arrangement appeared by way of chance. The authors [20] stated that Pearson used fundamentally the same formulae for chi-square models (goodness of fit, independence, homogeneity). Chi-square, typified as $\chi^{2}$, is a non-parametric test of significance. In this technique imperative data needs to be in the form of frequency counts occurring in two or more mutually exclusive categories [21]. In this study a chi-square test is used to compare the observed proportions as against the expected to help determine whether they are significantly different.

\section{Regression Model}

According to scholar [22] regression analysis model could be used effectively to help investigate relationship between a single, continuous outcome variable and two or more continuous, predictor variables. Similarly another author [23] described that multiple linear regression requires one dependent and more than one independent variables. In this study the regression model is used to test the null hypothesis related to factor conditions and its influence on the performance of the firms.

\section{E. Ethical Considerations}

The structured questionnaire along with covering letter from the researcher was furnished to survey participants (chief executives and senior managers) detailing therein the purpose of the study coupled with the introduction of the researcher and indicating ethical doctrine to be followed by researcher during all stages of the research and under all circumstances keeping the aspect of anonymity and confidentiality of participant(s) /respondent(s) in high consideration.

\section{RESULTS AND FINDINGS}

\section{A. Response Rate (RR)}

The data used in the study analysis was collected from 166 out of the 194 structured questionnaires distributed among the chief executives, and senior managers from the cross-functional areas of the automotive firms in Pakistan. The response rate was $85.6 \%$ representing adequacy in drawing the valid findings and the recommendations. While comparing the past doctoral strategic management studies RR in East Africa [24] documented $66 \% \mathrm{RR}$. 


\section{B. Mean and Standard Deviation for Factor Conditions}

In the study arithmetic mean was computed and arrived at the value which is invariably and mostly equidistant from all the values in the dataset. The majority of respondents gave their concurrence that national infrastructure (e.g. transportation, communication, education systems) support value creation reflected through the scale of mean score of 4.29.

Factor conditions such as skilled labor determine the productivity also reflects high scale as mean score of 4.27 was recorded. Considerable number of participants maintained the perspective that human capital in the firm leads the organization to enjoy high performance as shown by mean score of 4.02 .

Respondents also upheld the point that human capital, that is, competent human resources, is more important than basic factors for firm's performance as presented by mean score of 3.89. On the question of factor conditions determinant of Porter's diamond that shortage of labor leads to a situation where firms start utilizing resources productively in Pakistan automotive industry, lowest mean score of 3.20 was recorded vis-à-vis other statements in factor conditions incorporated in the questionnaire. Table 2 provides the outcomes related to mean and standard deviation for factor conditions.
TABLE 2. Mean and Standard Deviation for Factor Conditions

\begin{tabular}{|c|c|c|c|}
\hline & \multicolumn{3}{|c|}{ Factor Conditions } \\
\hline & $\mathrm{N}$ & Mean & SD \\
\hline $\begin{array}{l}\text { Factor conditions such as skilled labor } \\
\text { determine the productivity of the firm. }\end{array}$ & 166 & 4.27 & .680 \\
\hline 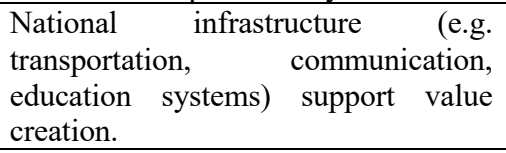 & 166 & 4.29 & .714 \\
\hline $\begin{array}{l}\text { Firm's productivity gets support from } \\
\text { national infrastructure. }\end{array}$ & 166 & 4.07 & .701 \\
\hline $\begin{array}{l}\text { Infrastructure of firm determines the } \\
\text { productive activity of the firm. }\end{array}$ & 166 & 4.12 & .695 \\
\hline $\begin{array}{l}\text { Advanced factors such as knowledge } \\
\text { are more important than basic factors } \\
\text { for firm's performance. }\end{array}$ & 166 & 3.76 & .902 \\
\hline $\begin{array}{l}\text { Human capital (i.e. competent human } \\
\text { resources) is more important than } \\
\text { basic factors for firm's performance. }\end{array}$ & 166 & 3.89 & .853 \\
\hline $\begin{array}{l}\text { Factor conditions are the compulsory } \\
\text { inputs which are required by the } \\
\text { organization for performance. }\end{array}$ & 166 & 3.87 & .759 \\
\hline $\begin{array}{l}\text { Human capital in the firm lead the } \\
\text { organization to enjoy high } \\
\text { performance. }\end{array}$ & 166 & 4.02 & .904 \\
\hline $\begin{array}{l}\text { Organizational knowledge in the firm } \\
\text { lead the organization to enjoy high } \\
\text { performance. }\end{array}$ & 166 & 4.04 & .823 \\
\hline $\begin{array}{l}\text { Organizations compete effectively in } \\
\text { the market with compulsory inputs of } \\
\text { factor conditions. }\end{array}$ & 166 & 3.86 & .730 \\
\hline $\begin{array}{l}\text { Competitiveness of the industry } \\
\text { cluster (i.e. group of similar/related } \\
\text { firms) in a defined geographical area, } \\
\text { is determined by the availability of } \\
\text { factors of production within the } \\
\text { cluster. }\end{array}$ & 166 & 3.75 & .742 \\
\hline $\begin{array}{l}\text { Factors of production within the } \\
\text { cluster lead to have national } \\
\text { competitive advantage for the firm. }\end{array}$ & 166 & 3.85 & .657 \\
\hline $\begin{array}{l}\text { Shortage of labor leads to a situation } \\
\text { where firms start utilizing resources } \\
\text { productively. }\end{array}$ & 166 & 3.20 & 1.012 \\
\hline $\begin{array}{l}\text { Firm's competitiveness depends upon } \\
\text { the efficiency with which factors have } \\
\text { been utilized. }\end{array}$ & 166 & 4.05 & .681 \\
\hline $\begin{array}{l}\text { Firm's performance is dependent } \\
\text { upon human resource strategies (e.g.) } \\
\text { hiring, training, retaining the human } \\
\text { capital) of the organization. }\end{array}$ & 166 & 4.20 & .767 \\
\hline
\end{tabular}

SD (Standard Deviation)

\section{Correlation Model}

The strength of a linear relationship between paired data was statistically measured by Pearson's correlation coefficient in the study focusing on automotive industry involving 166 respondents. In the study Pearson's coefficient was used on normal variables (factor conditions as the determinant of Porter diamond being independent variable and firm's performance operating in the automotive sector of Pakistan being dependent 
(variable) and linear association measured on paired data. Pearson's correlation coefficient test results found out that factor conditions being independent determinant do influence firm's performance in the automotive industry of Pakistan as they are positively and linearly related $r=.251, p<.01$. Two asterisks provide the identification. Table 3 indicates the results on correlation between factor conditions index and firm's performance.

TABLE 3. Correlation between Factor Conditions Index and Firm's Performance

\begin{tabular}{|l|l|l|}
\hline \multicolumn{2}{|c|}{} & $\begin{array}{l}\text { Firm's } \\
\text { Performance }\end{array}$ \\
\hline Factor Conditions & $\begin{array}{l}\text { Pearson } \\
\text { Correlation }\end{array}$ & $.251^{* *}$ \\
\cline { 2 - 3 } & Sig. (2-tailed) & .001 \\
\cline { 2 - 3 } & $\mathrm{N}$ & 166 \\
\hline
\end{tabular}

**. Correlation is significant at the 0.01 level (2-tailed)

\section{Chi-Square Test}

Chi-square test is nonparametric test of significance used in the study to compare observed results with expected results and to assess how well a sample fits the distribution of a known population (goodness-of-fit). Chi-square test statistics results show and conclude that there is association between Porter's diamond attribute factor conditions and firm's performance $x^{2}(26.284, \mathrm{df}=6, \mathrm{~N}=166, \quad p=.002)$. Table provides the results of chi-square test on factor conditions.

TABLE 4. Chi-Square of Factor Conditions Effect on Firm's

\begin{tabular}{|l|l|l|l|}
\multicolumn{1}{c|}{ Performance } \\
\hline & Value & Df & $\begin{array}{l}\text { Asymp. Sig. (2- } \\
\text { sided) }\end{array}$ \\
\hline Pearson Chi-Square & $26.284^{\mathrm{a}}$ & 6 & .000 \\
\hline Likelihood Ratio & 20.017 & 6 & .003 \\
\hline $\begin{array}{l}\text { Linear-by-Linear } \\
\text { Association }\end{array}$ & 9.587 & 1 & .002 \\
\hline N of Valid Cases & 166 & & \\
\hline
\end{tabular}

a. 6 cells $(50.0 \%)$ have expected count less than 5 .

The minimum expected count is .06

\section{E. Regression Model \\ F. Model Summary}

The model summary depicts how the factor conditions determinant affects and predicts firm's performance in the automotive industry of Pakistan by using the regression analysis outputs. $\mathrm{R}$ explained the relationship between the observed values and predicted values of the dependent variable, that is, firm's performance. The value of $\mathrm{R}$ maintains -1 to 1 range. The $\mathrm{R}$ sign depicts the direction of positive or negative relationship. In the model summary $r=.244$ indicated the strength of factor conditions as a determinant of firm's performance and the relationship which is positive. The coefficient of determination $\mathrm{R}$ square is .060; it means that $6 \%$ of variation in the performance of Pakistan automobile firms is caused by factor conditions. The remaining $94 \%$ is caused by other factors not considered in the study together with the error term. Table 5 provides the results.

TABLE 5. Model Summary of Factor Conditions Effect on Firm's Performance

\begin{tabular}{|c|c|c|c|c|c|}
\hline Model & $\mathrm{R}$ & $\begin{array}{l}\mathrm{R} \\
\text { Square }\end{array}$ & $\begin{array}{l}\text { Adjusted } \\
\mathrm{R} \\
\text { Square }\end{array}$ & $\begin{array}{l}\text { Std. Error of } \\
\text { the Estimate }\end{array}$ & $\begin{array}{l}\text { Durbin- } \\
\text { Watson }\end{array}$ \\
\hline 1 & $.244^{\mathrm{a}}$ & .060 & .054 & 1.68461330976 & 1.409 \\
\hline
\end{tabular}

a. Predictors:( Constant),Factor Conditions

b. Dependent Variable : Firm's performance

\section{G. Analysis of Variance (ANOVA)}

Apart from R-squared as explained above, analysis of variance (ANOVA) is applied to investigate how regression model fits the data appropriately. The F statistics indicate the regression mean square divided by the residual mean square. In the event significance value of $F$ statistics is lower than 0.05 ; it is inferred that the independent variable performed an appropriate job in describing the variation in dependent variable. From the model findings $\mathrm{p}$-value $=.002$, meaning thereby that regression model is significant, $\mathrm{F}=10.423$, $\mathrm{df}=1$, $<.05$, therefore concluding that model is statistically significant in predicting the relationship between Porter's diamond determinant factor conditions and firm's performance. Table 6 provides the outcomes on ANOVA of factor conditions effect on firm's performance.

TABLE 6. ANOVA of Factor Conditions Effect on Firm' Performance

\begin{tabular}{|l|l|l|l|l|l|l|}
\hline \multicolumn{2}{|l|}{ Model } & $\begin{array}{l}\text { Sum of } \\
\text { Squares }\end{array}$ & Df & $\begin{array}{l}\text { Mean } \\
\text { Square }\end{array}$ & F & Sig. \\
\hline \multirow{3}{*}{1} & Regression & 29.581 & 1 & 29.581 & 10.423 & $.002^{\mathrm{a}}$ \\
\cline { 2 - 8 } & Residual & 465.419 & 164 & 2.838 & & \\
\cline { 2 - 7 } & Total & 495.000 & 165 & & & \\
\hline
\end{tabular}

a. Predictor: (Constant),Factor Conditions

b. Dependent Variable: Firm's Performance

\section{H. Coefficients of Factor Conditions}

In the study it was found out that Porter's diamond first determinant factor conditions significantly predicted the firm's performance, $\beta_{0}=-4.345, \beta_{1}=1.100, p=.002$ (less than $\left.<.05\right) \mathrm{p}$ value was less than $<.05$ set by the study. The model implies that for every unit increase in Porter's diamond determinant factor conditions, firm's performance increases by 1.100 units in the automotive industry of Pakistan. The study found out that factor conditions significantly predicted firm's performance thus rejected the null hypothesis, $\mathrm{H}_{1}$ : Porter's diamond factor conditions determinant does not affect firm's performance. Table 7 presents the statistical test results of coefficients of factor conditions effect on firm's performance. 
TABLE 7. Coefficients of Factor Conditions Effect on Firm's Performance.

\begin{tabular}{|c|l|l|l|l|l|l|}
\hline \multicolumn{2}{|c|}{ Model } & \multicolumn{2}{|l|}{$\begin{array}{l}\text { Unstandardized } \\
\text { Coefficients }\end{array}$} & $\begin{array}{l}\text { Standardized } \\
\text { Coefficients }\end{array}$ & \multirow{1}{*}{} & \\
\cline { 3 - 7 } \multicolumn{2}{|c|}{} & B & $\begin{array}{l}\text { Std. } \\
\text { Error }\end{array}$ & Beta & T & Sig. \\
\hline 1 & Constant) & -4.345 & 1.352 & & -3.213 & .002 \\
\cline { 2 - 7 } & $\begin{array}{l}\text { Factor } \\
\text { Conditions }\end{array}$ & 1.100 & .341 & .244 & 3.229 & .002 \\
\hline
\end{tabular}

a. Predictors: (Constant), Factor Conditions

b. Dependent Variable: Firm's Performance

\section{DISCUSSION OF RESULTS}

The study sought to analyze the effect of factor conditions attribute on the performance of the automotive industry in Pakistan. The results of correlation analysis between Porter's diamond factor conditions and firm's performance documented that factor conditions do influence firm's performance in the automotive industry of Pakistan as they are positively and linearly related $r=.251, p<.01$. These results are in agreement with Porter's (1990) theory that factor conditions attributes such as resources: physical, financial, and human resource and quality of infrastructure lead the firm to perform competitively and realize the national competitive advantage (NCA).

The study on the automotive industry of Pakistan found out that factor conditions and its sub-constructs have direct association with performance like, skilled labor in the automotive industry of Pakistan is critical source leading to productivity for the organizations across progressive manufacturers and assemblers of trucks and buses, cars and light commercial vehicles (LCVs), motor cycles, and three wheelers. The study results found out that advanced factors such as knowledge are more important than basic factors for firm's performance in the dynamic environments in which automotive industry is operating in order to remain competitive with a view to realize national competitive advantage leading to improving the organizational performance.

These findings corroborate with Porter (1990) who maintained aptly that human capital considered as advanced factor has greater importance. These results are also in congruence with the results of [11] study in Himachal Pradesh, India which noted that human capital has a critical role in providing impetus for competitiveness and performance of firms in the sectors like, pharmaceuticals, food, automobile, electrical \& electronic goods and textiles as intangible factors influenced the competitiveness of medium and small enterprises, and these intangible resources are complex to be substituted and imitated by competitors.

The study results are also similar to the findings by researcher of [12] Makerere University Business School in relation to the contribution of intellectual capital at individual's level to gain CA. The author affirmed the view that for competitive advantage prediction three intellectual capital elements have 44 percent of variance in the CA which

DOI: http://dx.doi.org/10.24018/ejbmr.2019.4.4.78 according to their order of importance are; structural, human, and relational capital. In contrast, the researcher [13] using diamond in their study on Armenia reached the conclusion that in order to realize the future growth in the country, emphasis should be placed on encouraging competition \& rivalry in the industries and also on appropriate demand conditions attributes of Porter diamond.

On objectively based results the research study rejects the null hypothesis $\mathrm{H}_{1}$ : Porter's diamond factor conditions determinant does not affect firm's performance which is consistent with authors[1],[11],and [12] findings significant results and the arguments advanced in their studies. Discussion of results on factor conditions are consistent with the perspective that national factors of production encompass things and resources accessible to economic entities, such as physical, financial, and human resource including quality of infrastructure in a country's health care and education systems, transportation and communication networks Porter (1990).

\section{CONCLUSIONS}

The research study objectively sought to assess the influence of Porter's diamond determinant 'factor conditions' on the performance of firms in Pakistan's automotive industry. The study concluded that the broad based 'factor conditions' attribute of Porter's diamond framework affects the performance of progressive manufacturers and assemblers of trucks and buses, cars and light commercial vehicles (LCVs), motor cycles, and three wheelers performance and predicts an increase .060 for every boost in factor conditions in the automotive industry of Pakistan.

\section{RECOMMENDATIONS}

Based on the study results that relationship is positive and linear between Porter's (1990) diamond factor conditions determinant and firm's performance in the context of auto sector players of Pakistan, it is conclusively recommended for existing and potential auto industry players in Pakistan to realize the importance of factor conditions and its influence on firm's performance. Essentially the factor conditions subconstructs like: skilled labor, hard and soft infrastructure of firm, advanced factors such as knowledge, production within the cluster, the efficiency with which factors have been utilized in the operation of organizations in the automotive industry of Pakistan, could render impetus in improving the performance of firms, and eventually resulting into realizing the national competitiveness for the industry. Based on this research study it is further recommended that the government of Pakistan captures the full meaning and significance of Porter's diamond factor conditions determinant and aligns the automotive industry policy coupled with supportive measures including investment in national infrastructure to realize the national competitive advantage in the key automotive industry of Pakistan. Study results may provide impetus to capture and further enrich the broader perspective on Porter's diamond model and are useful for academia, practitioners and policy makers. The study recommends undertaking further empirical 
studies to determine the effect of Porter's diamond along with its broad based attributes especially on the critical role of advanced factors conditions to make contribution toward industry's competitiveness and the related policy measures governing the automotive industry in Pakistan.

\section{REFERENCES}

[1] Porter, M. (1990).The Competitive Advantage of Nations (1st ed.). Palgrave, New York Press.

[2] Rugman, A., \& Collinson, S. (2012). International business (6th ed.). Harlow, England; New York: Pearson.

[3] Jin, B., \& Moon, H. (2006). The diamond approach to the competitiveness of Korea's apparel industry Michael Porter and beyond. Journal of Fashion Marketing and Management : An International Journal, Vol. 10 Iss 2 pp. $195-208$.

[4] Grant, R.M. (1991). Porter's competitive advantage of nations: an assessment. Strategic Management Journal, Vol. 12 No. 7, pp. 535-48.

[5] Institute of Development and Economic Alternatives. (2016). Regional Competitiveness Studies Research Study on Auto Sector. Retrieved from http://www. ideaspak.org/images/sampledata/pdf- files /20160318-AutoSector-Report.pdf.

[6] State Bank of Pakistan (2015). Sector wise Studies' Report (2014-2015). Retrieved from http:/www.sbp. org.p/reports/annual/arFY15/Vol1/APRFY15(Complete).pdf

[7] Automotive Development Policy. (2016). Report 2016-2021. Retrieved frohttp://boi.gove.pk userfiles1/file/AutoPolicy/AP.pdf

[8] Imenda, S. (2014). Is there a Conceptual Difference between Theoretical and Conceptual Frameworks? University of Zululand, Faculty of Education, Department of Mathematics, Science and Technology Education, P/Bag x1001, KwaDlangezwa, South Africa.

[9] Karkkainen, R. (2008). Clustering and international competitiveness of information technology industry in the Saint Petersburg Area. ISBN 978952-214-599- 4.Retrieved from https:/www.doria.fi/bitstream/handle/ 10024/38568/Julkaisu RK Tuta.pdf?sequence $=1$.

[10] Macpherson, W., \& Lockhart, J. (2017).Understanding the erosion of US competitiveness: Managed education and labor in Japanese "corporate castle towns". Journal of Management History, Vol. 23 Issue: 3, pp.315-336. doi:org/10.1108/JMH-03-2017-0012

[11] Kharub ,M.,\& Sharma, R.(2017).Comparative analyses of competitive advantage using Porter diamond model (the case of MSMEs in Himachal).Competitiveness Review: An International Business Journal, Vol. 27 Issue: 2, pp.132-160.

[12] Kamukama, N. (2013).Intellectual capital: company's invisible source of competitive advantage. Competitiveness Review: An International Business Journal, Vol. 2 Issue: 3, pp.260-283.

[13] Chobanyan, A., \& Leigh, L. (2006). The competitive advantages of nations: Applying the "Diamond" model to Armenia. International Journal of Emerging Markets, Vol. 1 Issue: 2, pp.147-164.

[14] Jhamb, P. (2016). An Application of Porter's Diamond Framework: A Case of Sports Goods Cluster at Jalandhar. Pacific Business Review International, Volume 8, Issue 8.

[15] Sunders, M., Lewis, P. \& Thornhill, A. (2016). Research Methods for Business Students,(7th ed.). Pearson Education Limited.

[16] Malhotra, N.K. (2004). Marketing Research: An Applied Orientation (4th ed.) Pearson Education, Inc: New Jersey.

[17] Nunnally, J.C., \& Bernstein, I.H. (1994). Psychometric Theory (3rd ed.). McGraw-Hill:New York.

[18] Cooper, D. R., \& Schindler, P. S. (2014). Business research methods (12th ed). New York: McGraw Hill/Irwin 214

[19] Sekaran, U., \& Bougie, R. (2016). Research Methods for Business (7th ed.). John Wiley\& Sons Ltd.

[20] Franke, T. M., Ho, T., \& Christie, C. A. (2012). The Chi-square test: Often used and more often misinterpreted. American Journal of Evaluation, 33, 448-458 doi: org/10.117/109821 4011426594.

[21] Kothari, C.R. (2007). Quantitative techniques. New Delhi, UBS Publishers Limited.

[22] Thompson, B. (2006). Foundations of behavioral statistics: An insight-based approach. New York: The Guildford Press.

[23] Greene, H. (2017).Econometric Analysis (8th ed.). Upper Saddle River, N. J: Prentice Hall.
[24] Bagire,V.,\& Namada, J.(2013). Managerial Skills, Financial Capability and Strategic Planning in Organizations. American Journal of Industrial and Business Management.Vol.No.5.doi: 10.4236/ajibm. 2013.35055. 